\title{
The Contributions of Urban Landscape to Urban Life
}

\author{
Ahmet Tuğrul Polat* \\ Serpil Önder** \\ Ahmet Akay ${ }^{\star \star *}$
}

\begin{abstract}
The issues of urban and urbanization emerged after the industrial revolution. Thus, cities that have increased rapidly in population have become points of attraction for people. Over the past century, the world population has begun to gather quickly in urban areas. Cities are transforming into unhealthy living environments with distorted ecological balance, lost green areas and aesthetic qualities. The value of accessible green spaces in urban areas is increasing to the unprecedented levels. The green space system seen as a necessity in the cities have provided the emergence of the "urban landscape" phenomenon. The issue of urban landscape is now a very serious concept. The landscape change is moving along with the level of civilization. Primarily, guidance service should be offered for more efficient, comfortable and protective areas. An interdisciplinary approach is needed in the creation of urban spaces. In this study, the term of urban landscape was explained and the researches about the contributions of urban landscape to urban life were examined and suggestions were made about the subject.
\end{abstract}

Keywords: Open-Green Areas, Urban, Urban Landscape, Urban Life

*Assoc. Prof. Dr. Department of Landscape Architecture, Selçuk University, Konya, Turkey. E-mail: atpolat@selcuk.edu.tr

**Prof. Dr. Department of Landscape Architecture, Selçuk University, Konya, Turkey. E-mail: sonder@selcuk.edu.tr

***Research assistant, Department of Landscape Architecture, Selçuk University, Konya, Turkey.

E-mail: ahmetakay@selcuk.edu.tr 


\section{INTRODUCTION}

Cities that exist with the natural and physical environment, live a rapid process of change with the strong technological interventions and changing needs of today's world. Thus, cities that have rapidly increasing population have become points of attraction centres for people. The urban population in the world was approximately 2.5 billion in 1995, and this number is expected to be double around the year of 2025 (Loures, Santos, \& Panagopoulos, 2007; Melchert, 2007).

Cities reveal unhealthy living environments with their degraded ecological balance, lost green areas and aesthetic qualities (Melchert, 2007). Inadequate environmental policies, social and economic problems caused unsustainable construction, illegal occupation of the land and lack of environmental protection works, thus these are causing loss of green spaces. The value of accessible green spaces in urban areas is increasing to the unprecedented levels for the urban residents whose recreational needs are rising and characteristics are changing (Kizılaslan, 2007). The green space system seen as a necessity in the cities bring to light of the "urban landscape" phenomenon (Polat \& Önder, 2012).

Public (urban) spaces, also called open-green spaces are the common places that provide public interest opportunities surrounded by constructions in urban fabric. The main parts of these places are; parks, playground and sports areas, shopping areas, transit-assembly areas, zoos and botanical gardens, cemeteries and chapel gardens, open exhibition spaces and fairgrounds, historical and archaeological sites, coastlines, government agency gardens, urban forests and temporary open spaces (Hepcan, Kaplan, Küçükerbaş, \& Özkan, 2001).

Landscape change is acting in unison with the level of civilization. First of all, guidance should be made for more efficient, comfortable and protective areas. An interdisciplinary approach is needed in the creation of urban spaces. In this sense, profession experts such as architects, urban and regional planners, landscape architects and interior architects that constitute spaces have important tasks (Polat \& Önder, 2012).

The issue of urban landscape is now a very serious matter. Especially it is very important for local governments to protect and develop these resource values by taking the research results obtained about the subject into consideration. In this study, the concept of urban landscape was explained and the researches on the contributions of urban landscape to urban life were examined and suggestions were made about the subject. 


\section{URBAN LANDSCAPE}

Cultural landscapes are places where all or some of the natural assets or objects were modified, created and activated by humanity (Çubuk, 2001). Urban landscape is a kind of cultural landscape that is shaped by the cultural open spaces reserved for the benefit of more people and society. A conscious arrangement of the urban spaces is the expression of urban landscape. In urban space, it is the relation of structures to each other and to unstructured spaces as a whole. All urban factors and elements that generate the urban environment are being used in urban landscapes. In the formation of urban landscapes, there is a significant effect on the data about the socio-cultural structure as well as the physical structure (Karaman, 1992).

The main theme of urban landscape planning is the creation of an urban green space system (Pamay, 1978). The term of green space is defined as surface areas formed by covering or combining of existing open spaces with plants (woody and herbaceous plants) (Önder \& Polat, 2012). According to the by law numbered 23804, the term of green space is defined as the sum of playground, children's gardens, rest, excursion, picnic, entertainment and coastal areas reserved for community use. It is also being stated in the bylaw, 'international fairgrounds, botanical and zoo gardens and regional parks are also in the green area' (Anonymous, 1999).

The United Nations World Health Organization recommends that the amount of urban green space per capita should be at least 9 $\mathrm{m}^{2}$ for mitigating the undesirable environmental effects and for other benefits of these areas (Deloya, 1993). For the cities of Turkey, according to the provisions of the "Regulations on the Principles Regarding the Implementation and Modifications of the City Development Plan" published in the Official Gazette No. 23804 dated 02.09.1999; The green area amount per capita in urban areas should be at least $10 \mathrm{~m}^{2}$, and at least $14 \mathrm{~m}^{2}$ per capita outside municipal and contiguous area boundaries (Anonymous, 1999).

The determination of the amount of active green areas per capita in the cities of our country has considered in many scientific studies so that the deficiencies related to the amount of urban green spaces were tried to be kept on the agenda (Önder \& Polat, 2012). The studies show that the existing amount of active green area per capita is under the standards. For instance, these amounts of green areas were determined in some studies; $3.1 \mathrm{~m}^{2}$ in Antalya city (Ortaçeşme, Karagüzel, Atik, \& Sayan, 2000), $1.9 \mathrm{~m}^{2}$ in Istanbul (Aksoy, 2001), $3 \mathrm{~m}^{2}$ in Isparta (Gül \& Küçük, 2001), 
$1.02 \mathrm{~m}^{2}$ in Kars (Ylldiz \& Yllmaz, 2003), 5,44 $\mathrm{m}^{2}$ in Kayseri (Öztürk, 2004), $2.2 \mathrm{~m}^{2}$ in Kırıkkale (Özcan, 2006), $1.4 \mathrm{~m}^{2}$ Kahramanmaraş (Doygun \& İlter, 2007) and $4.01 \mathrm{~m}^{2}$ in Burdur (Yenice, 2012). According to the researches made in Konya, the amount of green area per capita is $12.53 \mathrm{~m}^{2}$ in Selçuklu District (Onder, Polat, \& Korucu, 2011), $59.27 \mathrm{~m}^{2}$ in Meram District, 9.93 $\mathrm{m}^{2}$ in Karatay District (Table 1) (Önder \& Polat, 2012). In European cities, this value is higher than our cities. Urban green areas are defined as "green spaces such as parks in the city open to public use" in the Urban Audit Report published by the European Commission (Taylor, Bozeat, Parkinson, \& Belil, 2000) and the average amount of the green areas per capita in 32 European cities for the year of 1996 is $26 \mathrm{~m}^{2}$. The amount of the green areas foreseen according to the Konya City Development Plans for the year of 2020 were given in Table 2.

Table 1. Konya City Central Districts' Green Areas (Önder \& Polat, 2012)

\begin{tabular}{|c|c|c|c|c|c|c|c|}
\hline \multicolumn{8}{|c|}{ Konya City Central Districts' Green Areas } \\
\hline \multirow[t]{2}{*}{ District } & \multirow[t]{2}{*}{ Population } & \multicolumn{2}{|c|}{ Playground } & \multicolumn{2}{|c|}{$\begin{array}{c}\text { Neighborhood } \\
\text { Park }\end{array}$} & \multicolumn{2}{|c|}{$\begin{array}{l}\text { Sport } \\
\text { Field }\end{array}$} \\
\hline & & $\begin{array}{c}\mathrm{m}^{2} \\
\text { (number) }\end{array}$ & $\begin{array}{c}\mathrm{m}^{2} / \\
\text { person }\end{array}$ & $\begin{array}{c}\mathrm{m}^{2} \\
\text { (number) }\end{array}$ & $\begin{array}{c}\mathrm{m}^{2} / \\
\text { person }\end{array}$ & $\begin{array}{c}\mathrm{m}^{2} \\
\text { (number) }\end{array}$ & $\begin{array}{l}\mathrm{m}^{2} / \\
\text { person }\end{array}$ \\
\hline Karatay & 232237 & $\begin{array}{c}44820 \\
(88)\end{array}$ & 0.19 & $\begin{array}{c}256782 \\
(117)\end{array}$ & 1.11 & $\begin{array}{c}41250 \\
(8)\end{array}$ & 0.18 \\
\hline Meram & 290297 & $\begin{array}{c}39450 \\
(71)\end{array}$ & 0.13 & $\begin{array}{c}465366 \\
(171)\end{array}$ & 1.60 & $\begin{array}{c}58035 \\
(12)\end{array}$ & 0.38 \\
\hline Selçuklu & 459921 & $\begin{array}{c}104512 \\
(229)\end{array}$ & 0.23 & $\begin{array}{c}415304 \\
(34)\end{array}$ & 1.11 & $\begin{array}{l}248 \\
499 \\
(72)\end{array}$ & 1.85 \\
\hline
\end{tabular}

Table 2. Green Areas foreseen in Konya City 2020 Development Plan (Önder \& Polat, 2012)

\begin{tabular}{lccccc}
\hline \multicolumn{6}{l}{ Green Areas foreseen in Konya City 2020 Development Plan } \\
\hline Districts & Population & $\begin{array}{c}\text { Recreation Areas } \\
\mathrm{m}^{2} \text { (Number) }\end{array}$ & $\begin{array}{c}\mathrm{m}^{2} / \\
\text { person }\end{array}$ & $\begin{array}{c}\text { Urban Park } \\
\mathrm{m}^{2} \text { (Number) }\end{array}$ & $\begin{array}{c}\mathrm{m}^{2} / \\
\text { person }\end{array}$ \\
\hline Karatay & 288930 & $4305216(2132)$ & 14.90 & $4726264(9)$ & 16.36 \\
\hline Meram & 330945 & $2116874(609)$ & 6.39 & $12285806(10)$ & 37.12 \\
\hline Selçuklu & 561946 & $7935578(5274)$ & 14.12 & $13634212(19)$ & 24.26 \\
\hline
\end{tabular}

\section{THE CONTRIBUTIONS OF URBAN LANDSCAPE TO URBAN LIFE}

\section{ECONOMIC CONTRIBUTIONS}

Energy saving: The most obvious function of urban forests in terms of economy is energy saving (Yılmaz, Bulut, \& Yeşil, 2006). Trees reduce the amount of energy used in buildings by the cooling effects in summer and by the windbreak function in winter (Dwyer, McPherson, Schroeder, \& Rowntree, 1992). McPherson and Gregory (1994) estimates that a tree with an average length of 6 meters reduces the annual heating-cooling cost of a house by 
8-12\%; Heisler (1986) also notes that plants save 8-12\% fuel consumption by reducing heat loss, by blocking wind flow and blowing snow or changing their direction. A forty-year-old ash tree in an urban forest reduces the cost of energy consumed for heating system by $7 \%$ with the shading effect and increases the price of the surrounding houses by $1 \%$. According to the results of E. G. McPherson (2004) and Akbari, Rosenfeld, and Taha (1989), studies, it has been shown that, 100 million mature trees (three trees for each house) save 2 million dollars in energy expenditures in the United States cities. Simpson and McPherson (1998) found that due to the reduction of heat loss by shading, each tree around the houses saved $\$ 14$, in a study conducted on a residential area with 254 houses.

Providing Tourism and Job Opportunities: The aesthetic, historical and recreational values of the urban landscape provide employment by increasing the attractiveness of the city and tourism revenues (Chiesura, 2004; Dunnett, Swanwick, \& Woolley, 2002). Art festivals organized in public parks, sporting competitions, food festivals, music concerts and theater shows provide significant positive economic contribution to the communities by bringing customers to local shops, restaurants and hotels (Sherer, 2006). Well-planned and managed urban parks revive the economic life in an area (Uzun, 2005). In addition, parks provide educational opportunities for the community and provide long-term employment opportunities for young people and adults to show their talents and experiences (Walker, 2004).

Hedonic Value: Many studies have revealed that green spaces or forest areas affects the prices of the surrounding houses and other immovable properties in urban areas (Yllmaz et al., 2006). The "Big Dig" project in Boston is a good example of mega-projects that create new green spaces in the city centre. A study based on the "hedonic pricing" method has been conducted to show the urban benefits of this project. It has been determined that property prices are affected positively in the vicinity of open green areas (Tajima, 2003). As a result of Luttik (2000) work it was found that especially environmental factors affected housing prices. For instance; while the price of a house side by side with the water feature increases by $8-10 \%$, the price of a house surrounded by green spaces increases by $6-21 \%$. It was found that in a survey carried out in Davis, California, USA, 24,000 roadside trees contributed $\$ 1.2$ million annually to the city by increasing environmental quality and the prices of immovable properties (Maco \& McPherson, 2003). According to the results of a study on a forestland near Aalborg city in Denmark, it was determined that house prices in the residential area increased by 273,000 Danish 
Kroner after the establishment of the urban forest (Hasler, Damgaard, Erichsen, Jørgensen, \& Kristoffersen, 2002). In evaluating the benefit analysis of Fairfax's urban forest, Virginia, has shown that a total of 57 million trees at Fairfax have been proven to be beneficial to the locality, socio-economically, annually at approximately \$ 398 million (Knapp \& Jordan, 1995). Increasing property values result in higher tax revenues for cities. In a study conducted in Colorado, it was estimated that the green area in a neighbourhood could generate $\$ 500,000$ a year in potential tax revenue. In the same study, the value of the houses near the green areas was measured to be $32 \%$ higher than the houses at 3200 feet away to these areas (Sherer, 2006). These studies support the willingness of people to voluntarily pay for houses near the park. In a national survey conducted by the National Association of Realtors in 2001, it was found that participants could voluntarily pay $10 \%$ more for houses near protected areas and parks (Bruch, 2006).

\section{ECOLOGICAL CONTRIBUTIONS}

Oxygen Production: The amount of the oxygen that trees produce in a year depends on carbon uptake of the tree biomass and the photosynthesis activity of the plant (Nowak, 2002). The annual net oxygen production of all plants in the world is $70 \times 109$ $t$ and the atmospheric oxygen is renewed every 17000 years. The amount of oxygen used in biological processes and given to the atmosphere remains almost the same, with only a few amounts of production. However, as a result of the burning of fossil fuels and the destruction of the vegetation cover, high amount of potential oxygen disappears (Barıs, Yazgan, \& Sahin, 2004; Bernatzky, 1982).

It is known that green plants, especially forests, give significant amounts of oxygen to the atmosphere by photosynthesis. For instance, a mature beech tree uses $2350 \mathrm{~g} \mathrm{CO}_{2}$ per hour and produces $1710 \mathrm{~g} \mathrm{O}_{2} .2350 \mathrm{~g}$ of carbon dioxide is the carbon dioxide produced by 10 families (40-50 people) per hour and $1710 \mathrm{~g}$ of oxygen equals to the daily oxygen requirement of 3 people (Pamay, 1978). A tree that grows in suitable ecological conditions produces enough oxygen for 10 people per year. A tree with a leaf surface area of $150 \mathrm{~m}^{2}$ produces enough oxygen for a person every year. A tree with a height of $25 \mathrm{~m}$ and a diameter of $14 \mathrm{~m}$ produces $1,799 \mathrm{~kg}$ of oxygen and $1,699 \mathrm{~kg}$ of dry matter per hour by using $0,960 \mathrm{~kg}$ of water and 2,352 kg of carbon dioxide (Uslu, 2007).

The US Forest Service has calculated that a tree produces $\$ 31,250$ worth of oxygen, $\$ 62,000$ in air pollution control, $\$ 37,500$ in 
water reclamation and $\$ 31,250$ in soil erosion control over a 50year lifetime (Sherer, 2006).

Filtering Dirty Air: Plants reduce pollution by filtering solid and gas particles in the air. Filtration of dust occurs in two ways. Active filtration; With active absorption and adsorption by the leaves of the trees. Passive filtration; by changing the direction and velocity of the air flows, the trees generate a turbulence with the sediments, as a result of this, passive dispersion and filtration with collapse occurs (Nowak, Crane, \& Stevens, 2006).

In an all-wood covered area (such as trees in parks), trees remove $15 \%$ ozone, $14 \%$ sulphur dioxide, $13 \%$ particulate matter, $8 \%$ nitrogen dioxide and $0.05 \%$ carbon monoxide. In addition, trees absorb nutrients such as phosphorus and potassium created by human activity. Otherwise, lakes and rivers become polluted (Sherer, 2006).

Trees can hold up to 5-10 times more dust than the current leaf weight. According to a survey conducted, it was determined that the amount of particulate matter in the atmosphere in wooded areas is less than in non-wooded areas. In the study, according to the results of 8 months of measurements, it was determined that the deciduous trees reduced the amount of dust in the atmosphere by $30 \%$ (rural) and 27\% (urban). According to the results, it was found that coniferous trees reduced the dust in the atmosphere by $42 \%$ in the rural environment and by $38 \%$ in the urban environment (Dochinger, 1980). Coniferous trees have more air cleaning capacity than deciduous trees due to the higher leaf area (Bolund \& Hunhammar, 1999). In a 5-year study conducted in France, an average of 3910 bacteria in $1 \mathrm{~m}^{3}$ of air were found in an area in Paris and this number decreased to 455 bacteries in a nearby park (Atay, 1990). According to another research conducted in the Sacramento urban forest, it was determined that the urban forest holds these amounts of air pollutants per hectare for one year; 10,9 kg in all study area, 13,9 $\mathrm{kg}$ in urban area and $4.2 \mathrm{~kg}$ in rural area (Scott, McPherson, \& Simpson, 1998).

Coolness Effect: A dome-like heat islands occur in cities due to the following reasons; dense heat absorbing construction in the horizontal and vertical direction and road materials (artificial surfaces such as asphalt, concrete, steel, glass, roof areas, etc.), reduction of wind speed because of high buildings, transferring large amount of the rainfall to underground with artificial drainage, prevention of the leakage into the soil by the impermeable materials and generation of smoke fog. In addition, the warmed air due to the lower wind speeds in the lower atmosphere layers in the cities is transported more slowly than in 
rural areas. This results in the heat of the cities being 8-12 ${ }^{\circ} \mathrm{C}$ higher than the surrounding rural areas (Özbilen, 1991). Areas such as parks, shaded corridors created by street trees, river corridors, valleys, areas where large shopping malls are located, industrial parks are the refreshing entrances in urban heat islands (Marsh, 2005).

The plants are functioning as regulators that regulate the temperature of the air. The plants reflect some of the solar rays hitting the top of the roof, absorb and diffuse some of it. For this reason, the weather becomes cooler in summer in shady places. In addition, the plants release water vapor during the transpiration of their leaves, which causes decrease of temperature (Yıldizcl, 1988). For instance, an umbrage tree with $21 \mathrm{~m}$ in length releases 400 litres of water a day in summer (Federer, 1976). In the urban environment, the temperatures under the trees are $5-8{ }^{\circ} \mathrm{C}$ higher than the open areas at night times (Atay, 1990). In a study conducted in Berlin, the temperature in a 212-hectare park was found to be $7{ }^{\circ} \mathrm{C}$ lower than the area where the buildings were located (Uslu, 2007).

In a summer day, about $1460 \mathrm{~kg}$ of water disappears from an average tree in gaseous form by transpiration. An average of 860 $\mathrm{mJ}$ of energy is consumed for this operation. The cooling effect caused by this energy is equivalent to an average of five air conditioners. Areas covered with trees have 10 times more cooling effect than grass areas (Uslu, 2007).

Reduction of Greenhouse Effect: Greenhouse effect is the result of preventing the sunlight from being reflected by the air pollutant gases again after entering the atmosphere. There are about 40 heat absorbing gases in the residential areas that are given to the atmosphere by mostly human activities. About half of the greenhouse effect is generated by $\mathrm{CO}_{2}$. Trees take store the carbon taken from the $\mathrm{CO}_{2}$ gas as cellulose in the wood tissue and leave the oxygen again in the atmosphere. A healthy tree can store about $6 \mathrm{~kg}$ of carbon per year or 2.6 tons of carbon per acre $\left(4047 \mathrm{~m}^{2}\right)$. Trees also reduce greenhouse effect due to shading effects. This effect reduces the requirements for cooling by $30 \%$ and so, it allows less fossil fuels to be used in the production of electric energy required for these processes (Barıs et al., 2004).

According to the Southern Karolina Forest Commission Report (1990), trees reduce greenhouse effect by up to $30 \%$ by reducing the amount of fossil fuel used for energy production. When field studies in 10 cities in the United States and national urban forests data are evaluated, it is determined that urban forests located in the US stored 700 million tons of carbon (by holding $\$ 22,8$ million 
tonnes of carbon, valuing at 460 million dollars annually), valuing at 14,300 million dollars. As a result, it is emphasized that urban forests play a significant role in reducing $\mathrm{CO}_{2}$ which is the dominant greenhouse gas (Nowak et al., 2006).

Prevention of Erosion and Providing Water Balance: Rainwater monitoring can be defined as detecting the amount and direction of surface water flow. In rainwater monitoring, urban green areas provide significant contributions to the prevention of surface water flow and the infiltration of rainwater surplus. In addition to the prevention of erosion, planted surfaces will be provided with water storage during the precipitation period and suitable environment for plant growth will be prepared (Başal \& Özdemir, 2008). Trees can manage the excess of surface water flow with more effective and less cost than sewages and drainage channels. Due to the fact that cities are covered with impermeable surfaces such as roads, pavements, car parks and roofs, the surface of the ground is prevented from the absorption of water and water problems arise. As the trees slow down the rainfall, the asphalt-free areas absorb the water and the runoff waters reach their stations slowly. American Forests, a conservation organization in the U.S., has found that trees in metropolitan areas save \$ 400 million in surface water retention systems (Beattie, Kollin, \& Moll, 2000; Sherer, 2006).

Although the amount of the rainfall retention depends on various factors, the coniferous plants can hold more rainfall. For instance, in pine forests, $60 \%$ of the rainfall can pass through the top of the forest to reach the soil but this amount reaches $80 \%$ on a forest covered with broad-leaved trees (Atay, 1990).

Ecological Restoration and Conservation of Biodiversity: Green areas help to restorate urban ecology with the greenery they cover. It is expected that the urbanization-damaged areas will be reconstructed with the natural systems in which general ecological principles are applied. Urban forests and parks create recycling models with low energy use, low chemical inputs, wellmanaged surface runoffs, and nature conservation (TrzesickaMlynarz, 2005). They provide habitats for the development and protection of birds, insects and other wildlife in cities. They also help people solve the problem of liaising with the animal world that has been lost in cities (Dwyer et al., 1992; Oğuz, 1998; Uzun, 2005).

Reduction of Noise: One of the major problems of the cities is the noise pollution with an increasing amount of damage in terms of human health. The traffic noise in the surrounding of the roads with the dense housing increases much more with the echo. In the 
roads around empty areas, the sound reaches far away easily. Undoubtedly, the most decorative obstacles against the noise are plants (Acar, 2006). Plants reduce or eliminate the negative effects of noise on people and the environment by absorbing the noises coming from various sources by means of green masses they formed. Plants with broad leaf, evergreen, frequent, large and hard leaf texture and branch form extending to the soil are more effective in the absorption of the noise. It has been proven by the scientific researches that noise can be reduced by up to $10 \mathrm{dBA}$ with the vegetative noise barriers implemented according to the technical principles (Fang \& Ling, 2003). Attention should be paid to the characteristics and type of vegetation used and technical principles for obtaining the desired result in vegetative noise barriers. Noise can be reduced around 10-12 dBA by noise barriers established in adequate width and length with proper plant species (Önder \& Polat, 2007). In a survey conducted in Konya, Turkey, it was determined that shrub groups composed with different plant species reduced the noise by $6.3 \mathrm{dBA}$ (Mutlu \& Onder, 2012).

\section{SOCIAL CONTRIBUTIONS}

Providing Education and Cultural Activities: Green spaces offer a wide range of educational opportunities. They provide services to help children and young people develop their skills, knowledge and trends with the help of community-based activities. Especially in places where children can easily reach their neighbourhoods, playgrounds are very important for children to develop their communication, business association, creativity, supervision skills (Dunnett et al., 2002; Sherer, 2006; Walker, 2004). Welldesigned parks are interesting in terms of history, culture, botany and wildlife. It is the realization area of ecological education. They allow urban people to establish the lost relationships with the plant and animal world in the city. Parks are places where growth processes of plants and some animals such as squirrels, butterflies and insects are observed. Parks provide pleasure of the ecological and biological awareness by changing the urban ecosystem (Kızılaslan, 2007; Oğuz, 1998; Sommer, Learey, Summit, \& Tirrell, 1994).

Reduction of Crime Rate: Recreational activities increase social development by reducing crime rates. Green spaces help people to relax and revitalize by reducing aggression. Access to parks and recreational activities is strongly linked to crime reduction, and in particular to the reduction of child crimes. Recreational activities keep young people away from the danger in the streets, provide them safe environments where they can provide group interactions and allow them to fully use the time without getting 
into other problems. According to Fort Myers, in the year of 1990, the police documented that the STARS (Academic and Recreational Support and Success) programme reduced the arrest rate for child offenses by $28 \%$ in Florida. The school achievement of young people has developed significantly. In a study of crime and recreation in Texas, it was found that the 1 mile-diameter midnight basketball reduced crime by 28\% (Bruch, 2006; Chiesura, 2004; Sherer, 2006).

Providing Opportunities for Recreational Activities: Urban landscapes form an organized outdoor space for recreational purposes. They prepare all the possibilities for active and passive recreation of people (Oğuz, 1998; Uzun, 2005). These areas allow entertainment, recreation, games and sports activities. Accessibility, availability and multifunctionality of green areas are important in terms of usage (Levent \& Nijkamp, 2005). According to a study conducted in Washington Seattle, USA, it has been found that the families with children frequently visit the parks than the other places in the neighbourhood and especially the vegetation factor is influential on these trips (Tilt, 2010). The result of a survey conducted in Hong Kong and China shows that parks are mostly used by older people and these users often prefer activities related to walking and physical exercise. It was determined that these activities contribute to their physical and psychological health (Wong, 2009).

Contribution to Social Development: Nature encourages the use of outdoor spaces, increasing social unity and interaction between neighbours (Chiesura, 2004). Parks are places where social relations can be established, which will allow for the development of social relations and increase solidarity. These areas are the places where people from different age groups and social classes come to meet and have different activities (meeting, encounter, walking, playing, chatting, etc.) (Peters, Elands, \& Buijs, 2010). In addition, all members of the community can use parks to reduce social tension and inform each other of social classes (Bruch, 2006). It can provide opportunities for intercultural interaction with the cultural characteristics of various ethnic groups (Peters et al., 2010). Surveys show that residents with more green areas have stronger social ties than those living in restricted concrete environments. In a survey conducted by Chicago and Illinois universities for urban people, it was determined that the development level of social bonds within the neighbourhood is proportional to the level of vegetation (Sherer, 2006).

Public Health Protection: Green areas have significant positive effects that cannot be underestimated on human soul and body 
health (Sanesi, Lafortezza, Bonnes, \& Carrus, 2006). Dense plant cover in people's living spaces is providing physical and spiritual relaxation (Müderrisoğlu, Eroğlu, Özkan, \& Ak, 2006).

According to researches about health, increasing physical activity decreases the mortality rate and provides psychological healing. Reduced physical activity can lead to heart disease, cancer, chronic lung disease, and diabetes. It has been determined that physical inactivity is the third leading cause of death at national level in the year of 2000 (Bruch, 2006). A survey conducted with 758 residents in Hong Kong by telephone interviews showed that parks are mostly used by older people, and the park users generally prefer walking and physical exercises. It was determined that they believe these activities contribute to their physical and psychological health (Wong, 2009).

The healing process of operated patients in a Pennsylvania hospital was investigated in a survey. While some patients have rooms with tree views, some of them are covered with brown brick walls. When the 10-year medical records were examined, on the comparison it was determined that the patients in the treeview rooms stayed shorter in hospital, used less painkillers, and received less negative comments in the nurse notes according to the brick-walled patients (Sherer, 2006).

Previous researches have shown that people living in urban areas show very different behaviours from people living in rural areas due to reasons such as crowd, noise, lack of open-green areas. In addition, it was revealed that by previous researches, the people living in houses without trees have committed more violence to their spouse and children than those who live in houses without trees in the surrounding areas. For instance, Kuo and Sullivan (2001) found that people living in near or in the vicinity of urban trees, were less likely to commit violence and bullying to their families than people living in houses with completely empty surroundings. In 2001, a comprehensive research result was published in the Netherlands with over 10,000 people to determine the link between green space and health. Results showed that people living in a green environment have less health complaints, feel healthier and have better mental health (Sherer, 2006).

\section{PHYSICAL CONTRIBUTIONS IN TERMS OF PLANNING}

A wide variety of open spaces can prevent undesirable core formation in dense residential areas and can have an impact on urban form with space structures they will create by dividing the city (Richter, 1981). They provide convenience in the city circulation by diverting vehicle and pedestrian traffic. 
It may allow to reduce population density in certain points of the city and for the realization of social activities. According to Richter (1981), some areas in the urban development process are protected by taking their future functions into consideration, and these areas can be temporarily offered to other uses.

Outdoor areas balance between people and their environment in terms of scale in the city. In cities where high buildings have an overwhelming scale effect on people, they lighten the oppression of open spaces over people and carry the spaces to the human dimension (Özbilen, 1991).

The plants have a great contribution to the visual quality of the urban environment. Vegetational materials used in these areas provide aesthetic value to the city with its features such as form, size, texture, colour and line. They enrich urban landscape with their colourful, lightened, and seasonal colour features from the aesthetic point of view by forming a contrast with artificial and inanimate elements of the city (Polat, 2010). In particular, the trees in the city freshen up the city by eliminating the city's aridity with their bulky greens and gain aesthetic presence with their colour characteristics depend on the seasons (Uzun, 2005). In cities, mass or surface conditioned green areas soften the hard and solid effects of architectural forms. Green areas camouflage undesirable objects and landscapes by masking appearance.

In the physical structure of the city, open green areas distinguish the different usage areas from each other and provide the physical balance of the city. They serve as a buffer between areas with different qualities such as accommodation, trade, work and education by contributing significantly to the structure of the cities. They equilibrate and establish an organic relationship between human beings and environment, structure and structure, structure and space. They are the equilibrium elements that reduce the density of the structures and community with their distribution in the city (Özbilen, 1991).

Urban landscape contributes to the preservation of historical and cultural heritage (Dunnett et al., 2002). Historical parks protected by restoration increase the awareness of the people in this area and at the same time they provide an opportunity to the preservation of historic areas. There are important projects that parks and recreation institutions have done in America. An important landscape restoration project was carried out on Prospect Park in Brooklyn, New York, designed by Frederick Law Olmsted and Calvert Vaux in 1886. The project is presented as an ecological restoration and historic preservation process. These projects combine natural ecological restoration with historical 
preservation of original design features. In this study, information gathered from questionnaires on park users was evaluated. It has been recognized that social and cultural experiences are historically significant by many park users (Taplin, 2002).

Sustainable development is considered as a strategic structure in urban parks which play a significant role in urban planning. Despite the fact that sustainability and urban renewal strategies focus on the man-made elements of the urban periphery, it is noteworthy that in recent years the interest in natural development in urban areas has increased (Loures et al., 2007). Some cities develop their own sustainability indicators to measure and test quality of life issues in a meaningful way. "The amount of green space per person", "parks" and "recreation areas" are often mentioned as an important factor in making a liveable, beautiful and charming city for citizens (Chiesura, 2004).

\section{CONCLUSIONS AND RECOMMENDATIONS}

The phase of city development planning is the first and most important step in terms of a healthy structuring of a city. At this stage, the most important problem arising from the planning related to the green spaces is that no green space system has been predicted in any of the city development plans. This is a fundamental deficiency that causes problems in all other cases. An erroneous green area determination policy is mostly being followed at the stage of the city development planning in our country. Informal, small surface parts of lands that are not suitable for use as a building site, and lands belonging to the treasury or foundations, are designated as green areas by this approach. It is not possible for these types of isolated and unevenly distributed green areas to fulfil the functions expected of them.

It is absolutely necessary to have a green space system forecast in the development plan phase. Urban green area systems were developed in the 19th century and applied in many European cities in the 20th century. It is of utmost importance to develop a green space system by taking advantage of green area system implementations which have many examples (such as the green belt, the green wedge, the green network, the green heart) in the world and taking into consideration the city's unique qualities. In our cities, it is absolutely necessary to have foresight of the green space system at the phase of city development plan. After the appropriate green area system is based, it is necessary to design the individual green spaces in sufficient size, to ensure the regular distribution of the projected green areas in the city, to connect the planned green areas with the green corridors and to bring an organic texture 
to the city. Because small and multi-part urban green areas have high maintenance costs and they will not allow wildlife to grow due to inadequate vegetative tissue, they will also cause a low number of people to benefit from these areas, and will cause some disadvantages in terms of area management and contribution to urban ecology.

When bringing small active green areas into service foreseen in the plan, these areas should be in ideal form and width, and designed to have a large settlement texture and to serve many people. It is sometimes impossible to create such a system in areas with dense housing and to turn back for ensuring its continuity. However, there is a chance to create a sustainable green space system in areas of development where construction has not yet begun or densified. In urban renewal projects, 'the possible green area transformation' philosophy should be adopted as a principle.

The design of urban landscape areas should primarily be in the example of natural landscape areas. In other words, success in urban landscape must be created in urban environments as good imitations of natural landscape areas. Landscape design criteria and landscapes shaped by discipline and monotony of urban life are insufficient to provide expected service.

The perceptions and preferences of urban people should be investigated in urban landscape design and applications. The obtained data will reveal the preference profiles of the users of that city. Urban landscape designs based on these data will be able to satisfy the urban people. Moreover, these studies can provide significant contributions to the identity of each city.

The most important phase of these studies is the "design process". The feasibility studies carried out, the measures to be taken and the resource analysis in this process will eliminate the problems that may arise in the implementation and management stages. The design process integrated with land and office work should be fully operated, not to be rushed, and these works should be done by landscape architects who are experts in this field.

Standards should not be ignored in the design and implementation of road landscapes, which are the most important elements of urban landscape. Shade trees should be preferred and located at appropriate points for roads.

Production of ornamental plants should be emphasized; especially native plant species should be produced. Healthy plants should be accepted and of plants which have problem in trunk, corolla and form should never be used in urban landscape. Principles of plantation design should be well researched and plantation should be completed according to these principles. 
Optimum utilization of green spaces will be achieved primarily by the adequacy of these areas in terms of location, size, accessibility, quality and presentation diversity and the establishment of appropriate use conditions for the people of the city. Hence, it is necessary to plan, design, implement and maintain the green areas adequately in urban areas. Maintenance works should be carried out on a weekly, monthly, seasonal and annual programme on time by competent persons.

In this regard, the park and garden departments of the local governments in the center of this process should be well organized in terms of design, implementation and management. These parts should be in coordination with each other at the same time as they carry a dynamism within themselves. One of the most important factors is to carry on every work through its own experts

\section{REFERENCES}

Acar, G. (2006). Alışveriş merkezlerinde peyzaj tasarımı. Ankara Üniversitesi Fen Bilimleri Enstitüsü Peyzaj Mimarlığı Anabilim Dall, Yüksek Lisans Tezi, Ankara.

Akbari, H., Rosenfeld, A., \& Taha, H. (1989). Recent developments in heat island studies: technical and policy. Controlling Summer Heat Islands, 15-30.

Aksoy, Y. (2001). İstanbul Kenti Yeşil Alan Durumunun İrdelenmesi, Doktora Tezi, İstanbul Teknik Üniversitesi. Fen Bilimleri Enstitüsü, 233.

Anonymous. (1999). 1999 tarih 23804 Sayılı İmar Yönetmeliği. Ankara.

Atay, İ. (1990). Kent Ormanları ve Çevre İle Etkileșimleri. İstanbul Üniversitesi Orman Fakültesi Dergisi, B40(1), 2-5.

Barıs, E. M., Yazgan, E. M., \& Sahin, S. (2004). Açık Alanların Ankara Kentinde Kent iklimi ve Hava Kalitesi Üzerine Etkileri Üzerine Bir Arastırma. Ankara Üniversitesi Bilimsel Arastırma Projesi Kesin Raporu, s, Ankara.

Başal, M., \& Özdemir, A. (2008). Sustainable Site Design Approaches-Sürdürebilir Peyzaj Tasarım Yaklaşımları (Vol. 1563). Ankara: Ankara Üniversitesi Ziraat Fakültesi Yayınları.

Beattie, J., Kollin, C., \& Moll, C. (2000). Trees help cities meet clean water regulations. American Forests (summer 2000), 18.

Bernatzky, A. (1982). The contribution of tress and green spaces to a town climate. Energy and Buildings, 5(1), 1-10 03787788.

Bolund, P., \& Hunhammar, S. (1999). Ecosystem services in urban areas. Ecological economics, 29(2), 293-301 0921-8009.

Bruch, S. P. (2006). Environmental Equity of Lansing's Urban Park Policy. (Doctorate Thesis), Michigan State University 
Chiesura, A. (2004). The role of urban parks for the sustainable city. Landscape and urban planning, 68(1), 129-138 01692046.

Çubuk, M. (2001). Kentsel Peyzaj Ders Notları. MSÜ Fen Bilimleri Enstitüsü, Şehircilik Anabilim Dalı Kentsel Tasarım Y.Lisans Programı. İstanbul.

Deloya, M. C. (1993). Urban forestry activities in Mexico. Unasylva, 173(44), 28-32.

Dochinger, L. S. (1980). Interception of airborne particles by tree plantings. Journal of Environmental Quality, 9(2), 265-268 0047-2425.

Doygun, H., \& İlter, A. A. (2007). Kahramanmaraş Kentinde Mevcut ve Öngörülen Aktif Yeșil Alan Yeterliliğinin İncelenmesi. Ekoloji Dergisi, 16(65 1300-1361).

Dunnett, N., Swanwick, C., \& Woolley, H. (2002). Improving urban parks, play areas and green spaces: Department for transport, local government and the regions London.

Dwyer, J. F., McPherson, E. G., Schroeder, H. W., \& Rowntree, R. A. (1992). Assessing the benefits and costs of the urban forest. Journal of Arboriculture, 18, 227-227 0278-5226.

Fang, C.-F., \& Ling, D.-L. (2003). Investigation of the noise reduction provided by tree belts. Landscape and urban planning, 63(4), 187-195 0169-2046.

Federer, C. A. (1976). Trees modify the urban microclimate. Journal of Arboriculture, 2(7), 121-127.

Gül, A., \& Küçük, V. (2001). Kentsel Açık-Yesil Alanlar ve Isparta Kenti Örneginde İrdelenmesi. Süleyman Demirel Üniversitesi Orman Fakültesi Dergisi, A(2), 27-48

Hasler, B., Damgaard, C. K., Erichsen, E. H., Jørgensen, J. J., \& Kristoffersen, H. E. (2002). The recreational values of forest, lake and nature restoration-valuation of nature goods using the hedonic price method. Energy and Environment. www. akf. dk/dk2002/summary/nature_restoration. htm.

Heisler, G. M. (1986). Energy savings with trees. Journal of Arboriculture, 12(5), 113-125.

Hepcan, Ş., Kaplan, A., Küçükerbaş, E. V., \& Özkan, B. (2001). Kemalpaşa (İzmir) Kentsel Dış Mekanlarının Yeterliliği Üzerine Bir Araştırma. E. Ü Ziraat Fakültesi Dergisi, 38(23), 143-150.

Karaman, A. (1992). Kentsel Peyzaj Ders Notları. MSGÜ, Şehir ve Bölge Planlama Bölümü. İstanbul.

Kızılaslan, S. (2007). Trabzon Kenti Park Ve Bahçelerinin Peyzaj Tasarım Kriterleri Açısından İncelenmesi. Yüksek Lisans Tezi Ankara Üniversitesi Fen Bilimleri Enstitüsü, Peyzaj Mimarlığı Anabilim Dall.

Knapp, M., \& Jordan, A. (1995). What are urban woodlands worth. Urban forest benefits analysis. Fairfax ReLeaf. Inc. Room, 828, 12011.

Kuo, F. E., \& Sullivan, W. C. (2001). Aggression and violence in the inner city effects of environment via mental fatigue. Environment and behavior, 33(4), 543-571 0013-9165.

Levent, T. B., \& Nijkamp, P. (2005). Evaluation of Urban Green Spaces. In D. Miller \& D. Patassini (Eds.), Beyond benefit 
cost analysis: accounting for non-market values in planning evaluation (pp. 63-87): Gower Publishing, Ltd.

Loures, L., Santos, R., \& Panagopoulos, T. (2007). Urban parks and sustainable city planning-The case of Portimão, Portugal. population, 15, 23.

Luttik, J. (2000). The value of trees, water and open space as reflected by house prices in the Netherlands. Landscape and urban planning, 48(3), 161-167 0169-2046.

Maco, S. E., \& McPherson, E. G. (2003). A practical approach to assessing structure, function, and value of street tree populations in small communities.

Marsh, W. M. (2005). Landscape planning: Environmental applications: Wiley New York.

McPherson, \& Gregory, E. (1994). Cooling urban heat islands with sustainable landscapes The ecological city: preserving and restoring urban biodiversity. Boston, MA: Univ of Massachusetts Press.

McPherson, E. G. (2004). Trees and energy conservation. Urban Forest Cut Energy Costs. www. americanforest. org.

Melchert, L. (2007). The Dutch sustainable building policy: A model for developing countries? Building and Environment, 42(2), 893-901 0360-1323.

Mutlu, Z., \& Onder, S. (2012). Investigation of the Noise Reduction Provided by Bush Belts in Konya, Turkey. Journal of International Environmental Application And Science, 7(1), 48.

Müderrisoğlu, H., Eroğlu, E., Özkan, Ş., \& Ak, K. (2006). Visual perception of tree forms. Building and Environment, 41(6), 796-806 0360-1323.

Nowak, D. J. (2002). The effects of urban trees on air quality. USDA Forest Service, 96-102.

Nowak, D. J., Crane, D. E., \& Stevens, J. C. (2006). Air pollution removal by urban trees and shrubs in the United States. Urban forestry \& urban greening, 4(3), 115-123 16188667.

Oğuz, D. (1998). Kent Parkı Kavramı Yönünden Ankara Kent Parklarının Kullanım Olgusu Üzerinde Bir Araştırma. Doktora Tezi Ankara Üniversitesi Fen Bilimleri Enstitüsü, Peyzaj Mimarlı̆̆ı Anabilim Dalı.

Onder, S., Polat, A. T., \& Korucu, S. (2011). The evaluation of existing and proposed active green spaces in Konya Seluklu District, Turkey. African Journal of Agricultural Research, 6(3), 737-747 1991-1637X.

Ortaçeşme, V., Karagüzel, O., Atik, M., \& Sayan, M. S. (2000). Antalya Kentinin Aktif Yeşil Alan Varlığı Üzerinde Bir Araştırma. Akdeniz Üniv. Ziraat Fakültesi Dergisi, 13(1), 11-22.

Önder, S., \& Polat, A. T. (2007). Yollarda Bitkisel Tasarım, Konya Kenti Örneği. Paper presented at the Kentsel Yeşil Dokunun Analizi ve Bakım Esasları Semineri, Konya.

Önder, S., \& Polat, A. T. (2012). Kentsel Açı-Yeşil Alanların Kent Yaşamındaki Yeri ve Önemi. Paper presented at the Kentsel Peyzaj Alanlarının Oluşumu ve Bakım Esasları Semineri, Konya. 
Özbilen, A. (1991). Kentiçi Açık Alanlar ve Dağılımı, Tarihi Eserler ve Gelișen Yeni Yapılașma. Orman Fakültesi, Genel Yayın(155).

Özcan, K. (2006). Sürdürülebilir Kentsel Gelişmede Açık-Yeşil Alanların Rolü, Kırıkkale, Türkiye Örneği. Ekoloji, 15(60), 37-45.

Öztürk, B. (2004). Kentsel Açık ve Yeşil Alan Sistemi Oluşturulması: Kayseri Kent Bütünü Örneği. Ankara Üniversitesi Fen Bilimleri Enstitüsü-Peyzaj Mimarlığı Bölümü. Ankara, 88.

Pamay, B. (1978). Kentsel peyzaj planlaması. İstanbul Üniversitesi Orman Fakültesi Yayınları, ÏÜ Yayın(2487).

Peters, K., Elands, B., \& Buijs, A. (2010). Social interactions in urban parks: Stimulating social cohesion? Urban forestry \& urban greening, 9(2), 93-100 1618-8667.

Polat, A. T. (2010). Kentsel Çevrenin Görsel Kalitesi ve Bitkiler. Plant, Peyzaj ve Süs Bitkileri Dergisi, 1(3), 20-23.

Polat, A. T., \& Önder, S. (2012). Kentsel Peyzaj: Tasarım ve Uygulamaya Yönelik Bazı Öneriler. Paper presented at the Kentsel Peyzaj Alanlarının Oluşumu ve Bakım Esasları Semineri, Konya.

Richter, G. (1981). Formen und Funktionen des Stadtgrüns. In G. Richter (Ed.), Handbuch StadtgrünLandschaftsarchitektur im städtischen Freiraum. BLV München: München, Wien, Zürich. BLV.

Sanesi, G., Lafortezza, R., Bonnes, M., \& Carrus, G. (2006). Comparison of two different approaches for assessing the psychological and social dimensions of green spaces. Urban forestry \& urban greening, 5(3), 121-129 16188667.

Scott, K. I., McPherson, E. G., \& Simpson, J. R. (1998). Air pollutant uptake by Sacramento's urban forest. Journal of Arboriculture, 24, 224-234 0278-5226.

Sherer, P. M. (2006). The Benefits of Parks. San Francisco, CA: The Trust for Public Land.

Simpson, J. R., \& McPherson, E. G. (1998). Simulation of tree shade impacts on residential energy use for space conditioning in Sacramento. Atmospheric Environment, 32(1), 69-74 1352-2310.

Sommer, R., Learey, F., Summit, J., \& Tirrell, M. (1994). Social benefits of resident involvement in tree planting: Comparison with developer-planted trees. Journal of Arboriculture, 20, 323-323 0278-5226.

Tajima, K. (2003). New estimates of the demand for urban green space: implications for valuing the environmental benefits of Boston's big dig project. Journal of Urban Affairs, 25(5), 641-655 1467-9906.

Taplin, D. H. (2002). Art, Nature, And People: Landscape Valves of An Urban Park. (Doctorate), The City University of New York New York

Taylor, D., Bozeat, N., Parkinson, M., \& Belil, M. (2000). The urban audit: towards the benchmarking of quality of life in 58 European cities (Volume 3: The urban audit manual). 
Luxembourg, European Commission (http://www. inforegio. cec. eu. int/urban/audit/ftp/volume3. pdff.

Tilt, J. H. (2010). Walking trips to parks: exploring demographic, environmental factors, and preferences for adults with children in the household. Preventive medicine, 50, S69S73 0091-7435.

Trzesicka-Mlynarz, D. (2005). Integrating Industrial Legacy Into Contemporary Urban Park Design: An Exploratory Study: University of Guelph.

Uslu, A. (2007). Kent Ekolojisi. In S. Gökmen (Ed.), Genel Ekoloji (Vol. 1160, pp. 353-401). Ankara: Nobel Yayınları.

Uzun, S. (2005). Kırsal Ve Kentsel Alanlardaki Parklarda Kullanıcı Memnuniyeti: Gölcük Orman İçi Dinlenme Alanı Ve İnönü Parkı Örneği. Yüksek Lisans Tezi Abant İzzet Baysal Üniversitesi Fen Bilimleri Enstitüsü, Peyzaj Mimarlığı Anabilim Dall.

Walker, C. (2004). The public value of urban parks: Citeseer.

Wong, K. K. (2009). Urban park visiting habits and leisure activities of residents in Hong Kong, China. Managing Leisure, 14(2), 125-140 1360-6719.

Yenice, M. S. (2012). Kentsel Yeșil Alanlar İçin Mekânsal Yeterlilik ve Erişilebilirlik Analizi; Burdur Örneği, Türkiye. SDÜ Orman Fakültesi Dergisi, 13, 41-47.

Yıldız, N. D., \& Yılmaz, H. (2003). Kars Kenti Açık ve Yeşil Alanlarının Sayısal Analizi/The Numerical Analysis of Kars City Open and Green Areas. Journal of the Faculty of Agriculture, 34(3 1300-9036).

Yıldızcı, A. C. (1988). Bitkisel Tasarım. Atlas Ofset, Istanbul.

Yılmaz, S., Bulut, Z., \& Yeşil, P. (2006). Kent Ormanlarının Kentsel Mekana Sağladığı Faydalar, Atatürk Üniversitesi. Ziraat Fakültesi Dergisi, 37(1), 131-136.

\section{Resume}

Ahmet Tuğrul Polat was born in Erzincan/Turkey. He is an associate professor in the Department of Landscape Architecture at the Faculty of Agriculture, Selcuk University in Turkey. His research interests focus on landscape design, ecotourism, urban parks and visual quality assessment in landscape architecture. He has been giving lectures at the undergraduate and graduate levels at Selcuk University.

Serpil Önder is a professor in the Department of Landscape Architecture at the Faculty of Agriculture, Selcuk University. She has articles and researches on key issues of landscape planning, open and green areas and environmental pollution. She has been giving lectures at the undergraduate and graduate levels at Selcuk University. 
Ahmet Akay is a research assistant in the Department of Landscape Architecture at the Faculty of Agriculture, Selcuk University. He received M.Sc. in Landscape Architecture (2015) degrees from Selcuk University, Konya, Turkey. 